\title{
The Effect of Think Pair Share in Social Science Learning Activity
}

\author{
Rr. Mirta Lidholyna Kumala Dewi \\ line 1 Pascasarjana Program Studi Pendidikan Dasar \\ Universitas Negeri Surabaya \\ Surabaya, Indonesia \\ rr.dewi16070855141@mhs.unesa.ac.id
}

\begin{abstract}
The aim of this research is to improve the students' learning activities through Think Pair Share (TPS) type using puzzle media. The Subjects are the fourth grade students of SDN Kepuh Kiriman I, Waru- Sidoarjo. This research uses a quantitative research design presented in the form of experimental research. To obtain the research data, the researcher uses observation sheets. The data are analyzed using a descriptive analysis. The result of this research shows that the students learning activity increase activity through TPS type using puzzle media. Advice given more time guiding students through group discussion so that students can actively work together in groups.
\end{abstract} (TPS)

Keywords-component; learning activity, Think Pair Share

\section{INTRODUCTION}

Indonesia is an archipelago country that causes the diversity of cultures and customs. Students as a youth of next generation of this country are obliged to preserve the cultures and customs as a form of love for the country.

The diversity owned by Indonesia is seen as a country's wealth that must always be preserved as a reason for division because of differences. Provision of the importance of unity and unity as citizens of Indonesia should begin to be invested from the family, school and community. Cooperation among the three components will produce the students who are not only smart in their intellectual ability but also polite in behaving.

The topics of Indonesian various cultures are studied in the fourth grade elementary school, using School Electronic Book by Anggari, Anggi St etc. In the learning process, the teacher makes a group consists of four people, than teacher uses the slides of the School Electronic Book, but the results are not happened as expected [1]. The tasks that should be done in groups are only solved by some members of the group, while the other group members choose to play alone and some even make a noise. When the teacher displays the slides, the students look unenthusiastic because the material shown is the same as the one in the book.

Learning is a process of communication that occurs between learners and educators who use the principle of education or learning theory as a major determinant of educational success [2].

Learning is a process of interaction between teacher, students and learning resources in the environment [3]

Based on the explanation above, the learning can be defined as an activity that involves two elements, teacher and students who interact or communicate in a learning environment, [4]

The creation of good learning activities can be influenced by several factors, namely the selection of learning models, [5] the use of media or props appropriate as well as the ability of teachers in mastering the class.

Based on the problems, the teacher will use cooperative learning model with Think Pair Share type because by using it the students can interact with their friends, discuss one another, express opinions and play the puzzle to complete the task of the teacher so that students will become more active [6].

[7] The formulation of the problem in this research is whether there is any difference in the learning activity of social science students of fourth grade elementary school between [8] cooperative learning Think Pair Share (TPS) type using Puzzle media with conventional learning in SDN Kepuh Kiriman I.

The research hypothesis is said that the learning activity of students SDN Kepuh Kiriman by using Think Pair Share (TPS) type using puzzle media is better than learning activities in conventional learning [9].

\section{METHOD}

The type of research conducted is a quantitative research with experimental methods. The variables in this research are Think Pair Share type using puzzle media as independent variable, than the dependent variable is learning activity.

This research is conducted on the fourth grade students of SDN Kepuh Kiriman I, Sidoarjo in 2018. The control class is IV C and the IV D students as the experimental class.

The procedure in this research is to implement the learning activity in accordance with the learning scenario that has been 
made in the sample class. [5] In the experimental class, the teacher applies the cooperative learning model Think Pair Share (TPS) type using puzzle media. The first step, the students should think individually, then discuss it with their peers in the same groups, and the last step the students should present the result of the group discussion in front of classmates from different group. The control class applies the conventional learning method. The instrument used in this research is observation sheet of student learning activities analyzed percentage technique.

\section{RESULTS AND DISCUSSION}

The data obtained during the students' learning activity each meeting by using the observation sheet can be described in the figure. The development of student activity in first meeting can be seen in figure 1 .

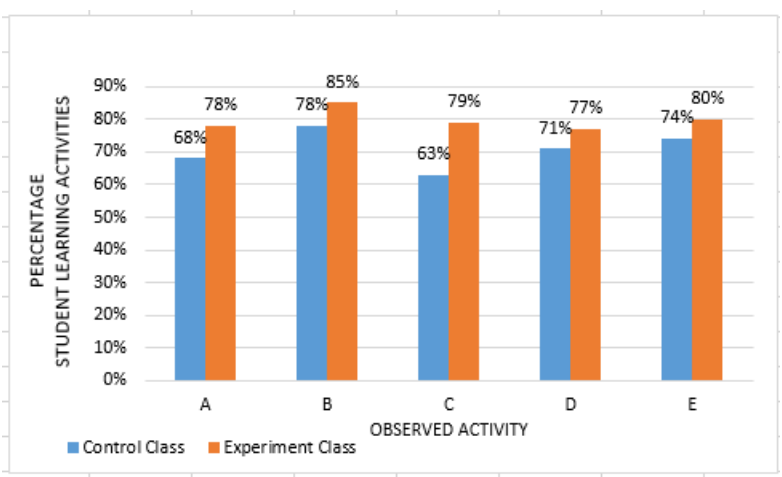

Figure 1. Graph of Student Learning Activities at The First Meeting

Note:
A : Preparation
B : Teamwork
C : Presentation
D : Conclusion
E : Closing

Based on Figure 1, it can be seen that the percentage of student activity in control class gets the lowest in the presentation activity and in experiment class they get the lowest in conclusion activity. The percentage of student activity in control class and experiment class get the highest in teamwork.

The development of student activity in second meeting can be seen in figure 2 .

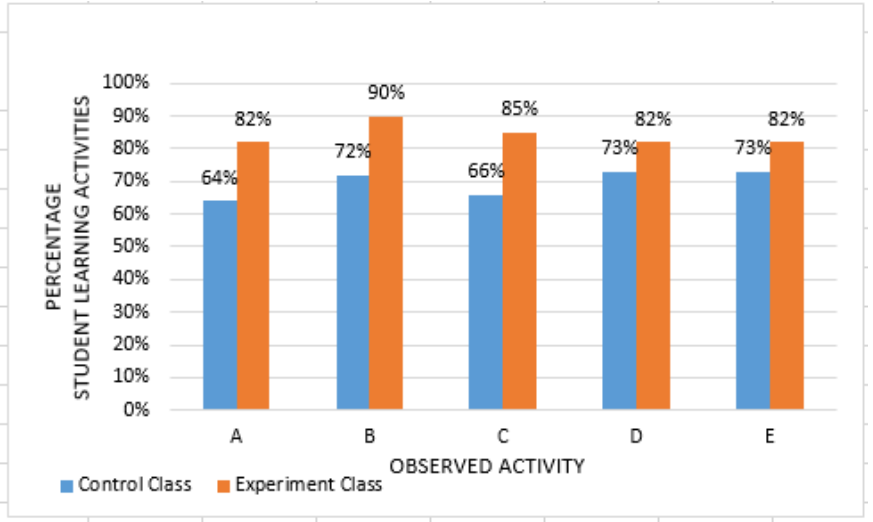

Figure 2. Graph of Student Learning Activities at The Second Meeting

Note:
A : Preparation
B : Teamwork
C : Presentation
D : Conclusion
E : Closing

Based on Figure 2, it can be seen that the percentage of student activity in control and experiment class get the lowest in preparation activity, conclusion and closing activity. The percentage of student activity in control class gets the highest in conclusion and closing activity and in experiment class the students get the highest in teamwork activity.

The average development of student activity can be seen in figure 3 .

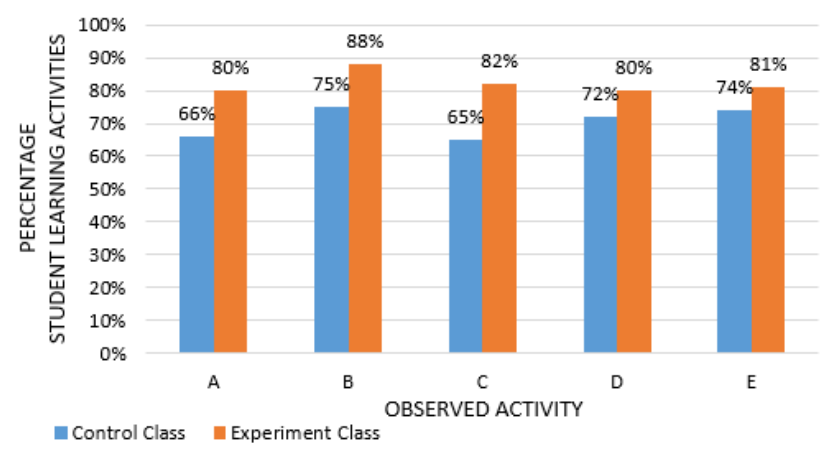

Figure 3. Graph of Average Student Learning Activities

$$
\begin{array}{ll}
\text { Note: } \\
\text { A } & \text { : Preparation } \\
\text { B } & \text { : Teamwork } \\
\text { C } & \text { : Presentation } \\
\text { D } & \text { : Conclusion } \\
\text { E } & \text { : Closing }
\end{array}
$$

Based on Figure 3, it can be seen that the percentage of student activity in control class gets the highest in teamwork activity $(75 \%)$ and in experiment class the students get the highest in teamwork too $(88 \%)$. This research proves that Think Pair Share (TPS) type using puzzle media in experiment 
class get a better result than conventional learning one in the control class.

This is in accordance with Vygotsky theory that the existence of social interaction can help the students to get a new knowledge and the Think Pair Share (TPS) type introduced by Frank Lyman can increase the students learning activities.

\section{CONCLUSION}

Based on the results of research, it can be concluded that the development of student learning activities with Think Pair Share (TPS) type using puzzle media increases in each meeting. It is proven by Qurtubhi that believes Think Pair Share type using puzzle media in experiment class can get better result than conventional learning in control class [10].

\section{References}

[1] M. Alpusari and R. A. Putra, "The application of cooperative learning think pair share (TPS) model to increase the process science skills in class IV elementry school number 81 Pekanbaru city," International Jornal of Science and Research (IJSR), vol. 4, pp. 2805-2808, 2015.
[2] S. Sagala, "Kemampuan profesional guru dan tenaga kependidikan," ed: Bandung: Alfabeta, 2009.

[3] C. S. Bos and S. Vaughn, Strategies for teaching students with learning and behavior problems: ERIC, 2002

[4] M. Huda, "Cooperative Learning metode, teknik, struktur dan model penerapan," Yogyakarta: Pustaka Pelajar, 2011.

[5] J. Melero and D. Hernández-Leo, "A Model for the Design of Puzzlebased Games Including Virtual and Physical Objects," Journal of Educational Technology \& Society, vol. 17, 2014.

[6] A. Fadholi, "Kelebihan dan kekurangan TPS," Diakses dari laman web tanggal, vol. 13, 2009.

[7] H. Hetika, I. Farida, and Y. P. Sari, "Think Pair Share (TPS) as Method to Improve Student's Learning Motivation and Learning Achievement," Dinamika Pendidikan, vol. 12, pp. 40-50, 2017.

[8] T. L. Emerson, L. K. English, and K. McGoldrick, "Evaluating the Cooperative Component in Cooperative Learning: A Quasi-Experimental Study," The Journal of Economic Education, vol. 46, pp. 1-13, 2015.

[9] M. Huda, "Model-Model Pengajaran dan Pembelajaran: Isu-Isu Metodis dan Paradigmatis: Pustaka Pelajar," 2014.

[10] W. M. Qurtubhi, "EFFECT OF COOPERATIVE LEARNING MODEL TYPE THINK PAIR AND SHARE (TPS) ON STUDENT COOPERATION (Quasi Experiments on Social Studies Learning Class VII in 1 Cikajang Junior High School)," International Journal Pedagogy of Social Studies, vol. 2, pp. 53-58, 2018. 